\title{
Film Technique: A Modern Economy of Time, Body, and Soul
}

\section{Juan David Cárdenas Maldonado}

Recibido: $15 / 04 / 2018$

Aprobado por pares: 29/05/2018
Enviado a pares: $18 / 04 / 2018$

Aceptado: 26/06/2018

DOI: 10.5294/pacla.2019.22.2.2

\section{Para citar este artículo / to reference this article / para citar este artigo}

Cárdenas, J. D. (2019). Film Technique: A Modern Economy of Time, Body and Soul.

Palabra Clave, 22(2), e2222. DOI: 10.5294/pacla.2019.22.2.2

\section{Abstract}

From its very grounds, cinematic expressions are conditioned by the set of a priori technical decisions taken even before any shooting could take place. Film technique allows the creation of images as much as it tends to prefigure possible experimentations and social appropriations. However, this repression has remained silenced because of the naturalization of the imitative, aesthetical and social function of film. It was only in the context of the modern comprehension of time, measured by exact and equal instants by the chronometric clock, that it was possible to invent a device that divided movement in precise and homogeneous instants to be reconstructed on the screen. Resonating with these researches on movement that permitted the development of film technique, new techniques of the body to calculate human perception and attention processes also appeared. Then, the body was not only an object of technical observation in terms of movement, but also in terms of mental activity. As much as the body was understood as a machine of movement, the soul was conceived as a measurable

1 orcid.org/0000-0001-8840-1412, Corporación Universitaria Unitec, Colombia. juancardenas@unitec.edu.co 
affective system. Finally, the ultimate strategy to make a priori technical presuppositions that remain invisible would be the automation and standardization of film devices. When technique is globally unified, the circle of naturalization is closed.

\section{Keywords (Source: Unesco Thesaurus)}

Cinema; cinematographic technique; body; attention; time; modernity. 


\section{Técnica cinematográfica: una economía moderna del tiempo, el cuerpo y el alma}

\section{Resumen}

Desde su base material, el cine está condicionado por una serie de decisiones técnicas a priori. La base técnica cinematográfica permite la creación de imágenes y prefigura posibles experimentaciones y apropiaciones sociales. No obstante, esta represión se mantiene silenciosa bajo la idea de que la técnica es neutra y por fuera de la historia. Este artículo se propone poner en cuestión esta evidencia. Solo en el contexto de la moderna concepción del tiempo fue posible la invención de un dispositivo que dividiera el movimiento en instantes exactos y homogéneos. Asociadas a estas investigaciones sobre el movimiento por la imagen, emergen técnicas de análisis del cuerpo y sus capacidades motoras, de percepción y de atención. Así, el cuerpo se convierte en un objeto de observación en lo relativo a su capacidad de movimiento, pero, a la vez, en lo que respecta a su actividad mental. Así, del mismo modo en que el cuerpo llega a ser entendido como una máquina, el alma es concebida como un sistema afectivo cuantificable. Todo esto está cristalizado en las formas a priori del diseño institucional de la técnica cinematográfica y una revisión histórico-conceptual puede traerlo a la luz.

\section{Palabras clave (Fuente: tesauro de la Unesco)}

Cine; técnica cinematográfica; cuerpo; atención; tiempo; modernidad. 


\section{Técnica cinematográfica: uma economia moderna do tempo, o corpo e a alma}

\section{Resumo}

Desde sua base material, o cinema está condicionado por uma série de decisões técnicas a priori. $\mathrm{O}$ fundamento técnico cinematográfico permite a criação de imagens e prefigura possíveis experimentações e apropriações sociais. Contudo, esta repressão permanece silenciosa sob a ideia de que a técnica é neutra e externa à história. $\mathrm{O}$ objetivo deste artigo é questionar essa evidência. Somente no contexto da concepção moderna do tempo foi possível inventar um dispositivo que dividisse o movimento em instantes exatos e homogêneos. Associadas com essas investigações sobre o movimento pela imagem, surgem técnicas de análise do corpo e de suas habilidades motoras, de percepção e de atenção. Assim, o corpo torna-se um objeto de observação em relação a sua capacidade de movimento, mas, ao mesmo tempo, em relação a sua atividade mental. Assim, da mesma forma que o corpo passa a ser entendido como uma máquina, a alma é concebida como um sistema afetivo quantificável. Tudo isso está cristalizado nas formas a priori do desenho institucional da técnica cinematográfica e uma revisão histórico-conceitual pode trazê-lo à luz.

\section{Palavras-chave (Fonte: tesauro da Unesco)}

Cinema; técnica cinematográfica; corpo; atenção tempo; modernidade. 


\section{Time, Motion Picture, and Modernity}

Deleuze's (1997) approach to Bergson's thesis on movement can help us introduce how modern cinematic machinery is, thus providing a general classification of historical conceptions of movement. In general terms, Deleuze distinguishes a classic conception of movement from a modern one, as well as an organic conception of movement from a mechanical one. For him, the classic conception of movement depends on a teleological comprehension of the world. That is why movement is understood through a set of privileged points that make change intelligible. "For antiquity, movement refers to intelligible elements, Forms or Ideas which are themselves eternal and immobile" (Deleuze, 1997, p. 4). As such, movement is conceived as the transition from one pose to another, from one privileged instant to another, regulated by ideal positions that guide it by providing it with intelligibility. According to different privileged instants, movements materialize an ideal plan: "Movement, conceived in this way, will thus be the regulated transition from one form to another, that is, an order of poses or privileged instants as in a dance" (Deleuze, 1997, p. 4). As in classic ballet, movement is understood as the transition between one pose to the next one. Accordingly, this transition is understood as a preparatory moment subordinated to the pose. Movement is, in fact, dependent on ideal poses or privileged instants, which implies that movement itself, that transition, is worthless compared to its target. We can thus find a hierarchy of instants at the base of movement.

In the context of modernity, the ideal and hierarchical comprehension of the classical approach to movement vanishes when the mechanical model of modern science destroys it. Movement stops being an intelligible transition between points and becomes a mechanical choreography. Deleuze (1997) presents it as follows: "The modern scientific revolution has consisted in relating movement not to privileged instants, but to any-instant-whatever. Although movement was still recomposed, it was no longer recomposed from formal transcendental elements (poses), but from immanent 
material elements (sections)" (Deleuze, 1997, p. 4). The modern conception of movement allows a mechanical explanation of change. Modern physics understands movement in a geometrical way by dividing it in homogenous fragments, thus rendering the analysis of movement as the sum of homogeneous instants. From the train to the cinematographic camera, modern devices depend on a repetitive mechanism that reproduces a homogeneous conception of movement. Film technology emerges in this context, not as a late consequence or as a second level phenomenon, but rather as an immanent expression of modernity. Film technology is an active part of modernity, not merely an epiphenomenon. The cinematic technological base is an embodiment of modern science, modern aesthetics and modern social life. Instant image, analysis of movement, controlled time for production: All these elements were social circumstances that surrounded the emergence of film technology.

The determining conditions of cinema are the following: not merely the photo, but the snapshot (the long-exposure photo [photo de pose] belongs to the other linage); the equidistance of snapshots; the transfer of this equidistance on to a framework which constitutes the film (it was Edison and Dickson who perforated the film in the camera); a mechanism for moving on images (Lumière's claws). It is in this sense that cinema is the system which reproduces movement of a function of any-instant-whatever that is, as a function of equidistant instants, selected so as to create an impression of continuity. (Deleuze, 1997, p. 5)

This is the final meaning of the modern analysis of movement: division in equidistant instants, without any privileged instants. As in contemporary dance, quite distant from classic ballet, there is no preference for certain poses. In consequence, modern time is a homogeneous time, where instants are not distinguished by a qualitative difference. As in a clock, modern time is mainly the sum of homogenous identities. Insofar as cinema was born in this context, the camera depends on the traditional mechanic machinery of the clock.

Henri Bergson criticized cinema precisely because of this mechanical division of movement. For him, cinema can only offer a poor representation of movement because of its material condition and it can merely 
provide a fake representation of movement twenty-four times per second. He stated that instant images could never reconstruct the continuous flow of time. However, he did not realize that, if the camera disintegrates movement, as it were, the projector brings back together what was previously separated and abstracted. Bergson did not take into account that cinema is not reduced to the materiality of film; it is not reduced to the simple succession of separated images. He disregarded the articulating work of the projector. Separated images become articulated in a continuous flow due to the projector's action. While the camera analyzes movement by dividing it, the projector synthesizes it by regaining its lost continuity. Thus, the image projected on the screen is not a sum of separated images, but a continuous flow of movement itself. Division and continuity are the two faces of cinematic device.

According to Mary Ann Doane (2002), this duality supports from the very base the modern conception of time and therefore the technical base of film technique. What does this duality involve? Doane (2002) states that the discussion on continuity and discontinuity was very intense because of the extreme importance that time gained in modern times as the main variable for production. Time became the main historical character when the clock turned the principle of production ${ }^{2}$. Thus, time became measurable and movement became predictable; the best example of this is the time inside the factory. One of the consequences of this, in the context of mechanical movement, was that any form of escape from control, any anomaly, became an object of study and concern. The counterpart of mechanic time is spontaneity and randomness; on the other side

2 There is a small but effective device, the main function of which consists in measuring time in abstract and identical unities. It is the chronometric clock that is absolutely different from any organic clock, such as water or sun clocks. The first mechanical clock appeared in the thirteenth century in contexts where discipline and work were very well appreciated. Benedictine monks were the ones who began using the new instrument. During the sixteenth century, this small machine became popular and it was necessary to unify in local scenarios the unities of measurement of time and, by the end of the century, the clock became part of the household. It turned into a personal device when, in the beginning of the nineteenth century, the industry of pocket clocks became the model of new industrial machinery. Finally, during the last two decade of that century, the Greenwich Meridian was funded to unify the European system of time according to the train and transport continental institutions (Sibilia, 2005, 18-19). 
of discontinuity there is the uncertainty of a continuous, non-manageable time. Doane (2002) introduces this emblematic modern concern this way: "The intense debates about continuity and discontinuity at the turn of the century, which support and inform discussions on representability of time, are a symptom of the ideological stress accompanying rationalization and abstraction" (Doane, 2002, p. 10). These antagonistic concerns about time are not separated; instead, they are like the two faces of Janus-they both belong to the same socio-historical strata. "The smooth narrative of a successful and progressive rationalization is also disturbed by an insistent fascination with contingency, indexicality and chance that manifests itself at many different levels" (Doane, 2002, p. 10). Rationalization of movement and time brings with it a will to control every hazard. The destruction of privileged instants expresses its last consequences in this fascination with chance and the ephemeral. For instance, photography was simultaneously the new media to capture the random instant and to study the body as a mechanical machine: Randomness and control were embodied in opposite uses of one of the most characteristic inventions of modernity. Contingency and strict causality are rooted in the same land:

Are these two tendencies within modernity-abstraction/rationalization and an emphasis upon the contingent, chance and the ephemeral-irreconcilable? Do they simply represent two different modalities or attitudes operating differently during the same time period, each undisturbed by the other? [...] It is possible to demonstrate their profound connection, their interdependence and alliance in the structuring of temporality in modernity [...] In the face of the abstraction of time, its transformation into the discrete, the measurable, the locus of value, chance and the contingent are assigned an important ideological role [...] Contingency appears to offer a vast reservoir of freedom and free play, irreducible to the systematic structuring of "leisure time". What is critical is the production of contingency and ephemerality as graspable, representable but nevertheless antisystematic. (Doane, 2002, pp. 10-11)

The rationalization of movement and time in the context of capitalism is correlative to an effort of structuring but also encouraging contingency and the chance to assimilate time and movement. Film technology emerged in the context of this dual concern. In fact, cinema is the way in 
which a mechanical idea of the world and an artistic expression can find a point of convergence in modernity. In other words, thanks to filmic representation, it is possible for the modern population to integrate mechanical technique into its ordinary life (Pezzella, 2004, p. 18). Cinema introduces proximity between machine and habitual world by allowing modern people to become accustomed to repetition and mechanicity and, simultaneously, to acceleration and randomness. Cinema introduced a new form of sensitivity for attention and dispersion, for mechanism and shock. In a film, modern control and modern excess cohabit.

A perfect materialization of this duality is crystallized in an early film from 1901. Filmed in New York by the Edison Company, What Happened on the Twenty-Third Street shows a crowded street, full of cars and pedestrians. A couple, husband and wife, approaches the camera on the sidewalk. When the woman walks over the subway ventilation grate, her long dress is blown up by accident and she immediately reacts by covering her legs with her skirt. The camera captured the accidental incident. Finally, what was supposed to be an ordinary street view turned into a sexual film of a naked female ankle. In this case, the sexual climax seems to depend on the capacity of film to capture random instants on the street, and spontaneity provides a plus of sexuality to the situation (Auerbach, 2007, p. 57). The couple was played by actress Florence Georgie and her husband: "While Porter's view starts out like a pure actuality, the blend of anonymous and professional actors is remarkable" (Sirois-Trahan, 2009, p. 107). The mixture of actual street people and actors expresses the combination of two times: the time of control and the time of randomness; the time of document and the time of fiction. What began as a documentary actually ended up as an invisible dramatization, where the random component was still in action. That is why a passerby reacts in a spontaneous way to act in response to what was really pre-conceived and so the document of naturalness and the preparation of fiction cohabit inside the frame.

We have in effect two rival modes of representation, two modes of objectification, two different ways that the boy and the woman each become acutely aware and center themselves -the camera eye outside the shot and the eyes of boyfriend and crowd gazing from within. (Auerbach, 2007, p. 57) 
The combination of appearance of spontaneous actuality with narrative control sheds a light on how, from the birth of instantaneous photography, technical images have inhabited the limit between control and spontaneity ${ }^{3}$, and cinematic technology crystallizes this duality. In other words, technical images embody a typical modern duality about time and movement and, thus, cinematic representation is expressive of modernity, no matter the quality or the content of the image. As in the theater of a modern city, everyday life, cinematographic camera and projector swing from one pole to its opposite.

Accordingly, Taylorism not only influenced the industrial system of filmic production, but was also interiorized by the camera. In a certain way, the cinematographic camera anticipated the Taylorist economy of time. The division of labors, the repetition of movements and the operative structure of industrial production were previously conceived as the structure of filmic time. From its technical foundation, cinema supposed a calculation of movement. "In Taylorism, each of the laborer's movements must be meaningful; ideally there is no loss or excess in the system. The body's movements are efficient and purposeful, and time becomes the measure of that efficiency" (Doane, 2002, p. 10). As in the Studio System, the cinematic technical devices respect an administrative conception of movement and time - the same as the laborer's body in the factory. There is more conti-

3 The ambiguous instrumental value of photography can be seen in other realms besides those of the art and amusement industries. It is possible to find examples of how the controlled rhetoric of corporal pose and the simulation of spontaneity live together in different contexts. For instance, George Didi-Huberman focused on the implementation of photography in the experimental environment of the Salpetrière hospital leaded by Charcot in nineteenth-century Paris. According to Didi-huberman, Charcot implemented photography to find out how the body of a patient of hysteria would behave. In order to capture the symptoms in images, he used to take pictures of patients, but when he was supposed to capture spontaneous images of the new female disorder, he implicitly asked them to pose for the camera. Photography was, in this case, a resource to establish a regular but natural catalogue of poses to describe the disease. However, it was a perfect mechanism to create a model for doctors and patients according to a clinical and aesthetical set of protocols crystallized in pictures and their correlative practices and discourses. That is why Didi-Huberman concludes that hysteria was more a product of a mixture of technical images and imagination than a trustable scientific discovery: "I will interrogate this paradox of atrocity at every moment of its history, hysteria was a pain that was compelled to be invented, as spectacle and image. It went so far as to invent itself (for this compulsion was its essence) when the talents of hysteria's established fabricators fell into decline. An invention is the event of signifiers" (Didi-Huberman, 2003, p. 3). Photography provided a perfect device to blend spontaneity and pose and due to that, it provided the scientific solution to the enigma of hysteria, that malady without inner corporeal signals. 
nuity among filmic technique, cinematographic system of production and factory than it is usually stated. But at the same time, just as the factory is the place cohabited by control and accident, and the city is the place where normalization shares space with random behavior, technical images, from instantaneous photography to video, are sensitive to contingency as well. "The technological assurance of indexicality is the warranty of a privileged relation to change and the contingent, whose lure would be the escape from the grasp of rationalization and its system" (Doane, 2002, p. 10). Modern time and modern devices to measure it freed movement from privileged instants, and so time became an object of administration and, additionally, a fleeting element free of the rule of the homogenous unities of measure. The cinematographic representation of time is not neutral but instead, historical; to be precise, it is industrial and modern. That is why the record of movement would soon become a perfect input for spectacle, that industry of images and imagination.

\section{Modern Time, Body and Cinematographic Technique}

According to Michel Foucault (1990), the emergence of industrial societies was enabled partly by a certain set of disciplines imposed on the human body. Industrial and disciplinary societies developed an intricate set of practices on bodies in order to model the modern mass. This work on bodies replaced the violent regime of slavery with a very sophisticated and subtly widespread set of practices and speeches on the body, which were consolidated in institutions such as hospitals, prisons, schools, and factories (Sibilia, 2005, p. 29). In terms of Foucault, the new power on life, biopolitics, partly focused on the body in order to preserve, but also to normalize people's behavior. There was a pole of power focused on the bodies' strengths, which was

centered on body as a machine: its disciplining, the optimization of its capabilities, the extortion of its forces, the parallel increase of the usefulness and its docility, its integration into systems of efficient and economic controls. All this was ensured by the procedures of power that characterized the disciplines: an anatomo-politics of the human body. (Foucault, 1990, p. 139) 
This work on the body entailed an adjustment of populations to a new regime of production. New sciences of human body and soul flourished in order to increase and normalize productive activities. "The investment of the body, its valorization and the distributive management of its forces were at the time indispensable" (Foucault, 1990, p. 41). However, the intervention on the body was not only at that institutional level. The worker's body at the factory was not the only one subject to regulation. Modern forms of experience were full of technical devices to quantify the movement of human bodies, of animal bodies and even of mechanic apparatuses. In the modern system of production everything becomes appropriable in terms of quantities. This means that every kind of movement becomes observable and analyzable, like the human body. A perfect manner to control the human body as a mechanism consists in making its behavior visible and analyzable instant by instant. The industrialization of bodies needed a form of transformation of the visibility of bodies. This new gaze was warranted by new technologies of the visible. "The whole world becomes visible at the same time it becomes appropriatable" (Comolli, 1980, pp. 122-123). What used to be a form of anatomo-politics on the body turned into an entire regime of visibility that entailed a permanent quantification of movement, of organic and non-organic movements. And this quantification was tied to a new set of mechanisms of vision that enabled the analysis of the entire reality as a machine. In other words, when mechanical reproduction was at the base of the manufacture of objects, the model of mechanism determined modern visual and perceptive aspirations. A modern industrial form of the gaze emerged parallel to the industrial mode of production.

\begin{abstract}
Thanks to the same principles of mechanical repetition, the movements of men and animals become in some sort more visible than they had been: movement becomes a visible mechanism. The mechanical opens out and multiplies the visible and between them is established a complicity all the stronger in that the codes of analogical figuration slip irresistibly from painting to photography and then from the latter to cinematography. (Comolli, 1980, p. 123)
\end{abstract}

The mechanic eye of the camera became the new modern human eye that cohabits with a new realm of forms of production and consumption, new forms of control and politics, new manners of knowledge and 
new practices associated to them, new forms of experience through art and spectacle. There was, in a general sense, a new objectivity (Benjamin, 2005, p. 156).

Jules Marey perfectly understood this new sensitivity. For him, instantaneous photography shed light on what is hidden to the human eye. It enables the truth of movement that was kept invisible for pre-modern people to be seen. Thus, photography allowed us not only to see a new reality but also to realize how insufficient was organic perception. This new technical eye was, for the French researcher, the clue to accurately approach the mechanicity of life and, finally, of reality. "Marey participated in a general movement in physiology in the later half of nineteenth century that involved the production of a concept of life adequate to modernity-a concept of life as process, movement, change" (Doane, 2002, p. 46). Due to this conception of life, organic bodies were no longer understood as organisms and began to be seen as mechanisms. The body turned into the visual surface of mechanical life.

Marey's ostensible object was movement, that is, the correlation of space and time as a body successively changes its position. It is therefore arguable that his interest in time was merely secondary, a by-product of the obsessive concern-more proper to a physiologist-with the analysis of bodies in motion. (Doane, 2002, p. 46)

For him, the measure of movement and the photographic register of the body were correlative. It is important to remember that Marey's research on movement began after a request from the army to find a more economic form of the soldier's march in order to reduce the effort and maximize the traveled distance (Oubiña, 2009, p. 60). Therefore, a mechanical approach to movement concealed an economical conception of the body's effort. If physiological functions became visible, they could turn into measurable information and, thus, they could be knowable in a scientific way, namely, objectivable. Marey's implementation of photography fits perfectly with the positivist system of values that proclaims calculation of objects in order to optimize productivity by using scientific knowledge as an instrument. The organic body, for Marey, like a train, was perfectible in terms of calculation and efficiency. This scientific will 
to science led Marey to a non-figurative exploration of the image. Marey's pictures tended, day by day, to achieve a less figurative presentation. Marey did not look for the illusion of movement, but rather strived to make visible the abstract line it traces in time and space (Oubiña, 2009, p. 82). In other words, he sought the abstraction to make movement knowable as image, an image of time as change.

Initially and apparently adhering to a body, movement was progressively disengaged from that body first through the technique of the geometric chronophotography and later through Marey's growing interest in the more apparently abstract and bodiless realms of fluid dynamics and the flow of air currents. (Doanne, 2002, p. 47)

According to this, for Marey, cinema reproduces the illusion of movement, and therefore it does not provide anything to knowledge or experience. His attempt to represent the trace of movement affected negatively the figuration of image. In consequence, it is valid to say that Marey produced images for scientists but he did not point to any ordinary spectator at all. It is precisely for this will to science that Marey implemented photography as an idealized tool. He considered the mechanical nature of the photographic device as an argument of transparency: "Photography was, in this respect, ideal, since it means of connecting object and representation-light waves - were literary intangible and greatly reduced the potentially corruptive effects of mediation" (Doane, 2002, p. 47). The mechanic eye of the camera was a neutral witness of the flow of material life, and the reality that appeared to the lens was an abstract trace. Transparency of technique naturally led Marey to abstraction.

In a similar case to Marey's, Edward Muybridge, a famous photographer in the second half of the nineteenth century, was commissioned to develop an experiment on animal movement by using photography. Leland Stanford, owner of many professional racehorses, asked Muybridge to analyze horses' movement while trotting at full speed (Hendricks, 2001, p. 100). Stanford wanted photographs of horses' movements at every stage, in order to implement photographic discoveries to increase the speed of horses at the races. Again, technical images were a tool to improve efficiency. Muybridge's experiment results were a novelty. The horses' legs were not stretched when 
they were in the air, as painting tradition had represented running horses ${ }^{4}$. Instead of that, Muybridge's pictures proved how horse legs remained curled while running. The discovery represented polemic news mainly in the context of European traditional arts: Traditional handcraft images of horses had been renewed by technical devises of vision.

This first break between photography and the codes of representation of the naturalistic painting of the nineteenth century made by Muybridge seems to me to be absolutely crucial, for, from a certain point of view, all the work of the Great Pioneers of cinema, was to consist of restoring to moving photography the beauty - that of bourgeois painting, but also bourgeois theater and novel-which Muybridge's innocent procedure had robbed of it. (Burch, 1990, p. 12)

Nevertheless, in an attitude inherited from the Renaissance, Muybridge projected his technical images to a broader social landscape than that of artisanal art. He understood his images could attract not only scientists such as Marey, but also a wider public.

\begin{abstract}
Suddenly the question was what to do with this unprecedented extension of visual possibilities. Muybridge recognized the research potential of his techniques and cultivated an air of scientific authority in articles and lectures. He also knew that painters, sculptures and draftspersons would be interested in this formerly unexplored world, and he touted the value of these photographs as artists' studies. His interest in this dimension of the work was sincere, yet it is wise to remember that his cultivation of different audiences also enabled him to generate sales. Muybridge was always concerned with the public acceptance of his work. (Prodger, 2003, p. 213)
\end{abstract}

This new modern sensitivity entails the projection of scientific discoveries into the world of spectacle and commodities. As it happened with

4 Western painting tradition used to represent horses running with their paws stretched out because that position was widely accepted not only in arts, but also in science and in general it was the common opinion. When Edward Muybridge exposed his images of running horses, artists — mainly painters — and some scientists, attacked him; then he had to prove that he did not intervene the technical device to make the pictures. One of the most repeated arguments involved Théodore Géricault's painting. His preference for horses and his painting skills made him a mandatory reference to counterargument Muybridge's images. Finally, as it was considered that the machine does not lie, Muybridge beat tradition. This example illustrates the transformation of the gaze and the sense of beauty in the rising of industrial modernity (Oubiña, 2009, p. 71). 
most philosophical toys, those visual devices resulting from scientific research on vision, Muybridge understood that science had an audience and his images could become an object of consumption. This proximity between science and spectacle is clearly evident when Muybridge's system of production is analyzed. To create each set of pictures on movement, Muybridge needed to mobilize as much energies as it would be needed in professional filmmaking decades later. Consequently, Muybrigde's experiments anticipated the requirement of paying back the investment (Oubiña, 2009, p. 89). After he stopped being supported by Stanford, he needed to design a kind of script in order to reduce costs. He also had to arrange the sessions, construct the décor of the location, and even direct the actors. To get the nude female pictures, Muybridge had to find prostitutes and pay them to pose for the camera. The financial element was a criterion of success. Even if the scientific rigor of Muybridge's experiment is doubtless, the proximity of science and staging has to be revealed. The body exposed by a salary, the nude female body exposed, is a constitutive element of the spectacle of scientific truth. The factory, the laboratory and the studio are closer than it is usually accepted.

As said above, Marey was mainly focused on abstract analysis of movement. Consequently, his studies led him far away from figurative representation. To Marey, photography had no representative value. On the contrary, Muybridge was seduced by a more figurative representation of movement and, thus, his images provided a very exploitable resource in the market of the emerging spectacle in the nineteenth century. The triumph of Muybridge's figurative task on the scientific abstraction of Marey is expressive of the figurative and narrative element implicitly contained in the cinematographic image from its technical base. Muybridge was closer to the anthropomorphous presuppositions of cinema than Marey. From the camera to the projector, Marey taught us how technical images could be different; nonetheless, the spectacle of figurative pictures had more success for consumption. In a certain way, technical devices enabled cinema as a spectacle, but, in contrast, they could also deny this destiny. In this manner, it makes sense to consider Marey closer to the avant-garde's visual experiments than to traditional cinematography. Nöel Burch (1990) describes this apparent 
paradox from some of Marey's words on his preference on visual experimentation over seductive figurative representation:

It is gratifying, but also instructive to compare such declarations with
those of Dziga Vertov-we cannot improve the making of our own
eye, but we can endlessly improve the camera-or Jean Epstein-a
documentary shot describing in a few minutes twelve months of the
life of a plant... seems to free us of terrestrial, i. e., solar time, of the
rhythm to which we seemed ineluctable bound. (Burch, 1990, p. 13)

To summarize, Marey and Muybridge are not only in the hinge of two different models of representation, but also in the scenario of a general transformation of the social life of images, a new social behavior of images that perfectly fits with the widespread sensitivity of consumption. In other words, from its very base, cinema had to fit with mass sensitivity in the context of capitalism to become the modern art par excellence.

From the moment Marey first saw Lumiéres' cinematic images, he felt disappointed. His experiment had been vulgarized to the level of entertainment. What could have been an instrument for science ended up being a commodity of mass consumption. Two decades later, amidst the emergence of Hollywood's industrial model, the Lumière brothers felt the same: They thought their invention had been vulgarized by the industry of spectacle (Oubiña, 2009, p. 83). However, this appropriation of cinematic technology was not simply an issue of isolated persons. If the Lumière brothers could construct the camera and the projector, it was possible because of some other previous technical inventions that were industrially successful. The change from Marey's chronophotography to Lumière's cinema was possible because of preexisting technical devices. For instance, a flexible plastic film was needed to enable a continuous and homogeneous flow of images. Lumière's insight consisted in the implementation of that celluloid, transparent film, to produce a permanent flow of pictures and, thus, to reproduce a perfect illusion of movement (Oubiña, 2009, p. 78). However, that effort would have been useless if a projector had not been simultaneously invented, one that normalized the speed of the flow of images in order to reproduce human perception of movement, as well as to hide the darkness between the frames. 
During the projection of a film, the spectator is sitting in an unperceived darkness for almost the 40 percent of the running time. Hence much of the movement of time allegedly recorded by the camera is simply not there, lost in the interstices between frames. These interstices, crucial for the representation of movement, must themselves remain unacknowledged. (Doane, 2002, p. 172)

Cinematic technology responded to a set of demands through a kit of technical protocols. In other words, Lumière's invention linked material devices and technical protocols to satisfy its time.

This will to rationalize movement as a continuous flow may find one of its most expressive instances in Frank B. Gilberth's work. Gilberth was a direct pupil of Taylor's theoretical legacy. "Designed to be an improvement on Taylor's methods, and thus to garner cooperation from worker and manager alike, Gilbreth's method of 'motion study' via motion picture and other visual technologies promised an even more thoroughly 'scientific' and 'objective' solution” (Curtis, 2009, p. 85). His visual experiment on workers' bodies crystallizes the desire to capture the flow of movement in order to make it efficient through mechanization, by using a neutral device for observation and an objective scientific and quantitative approach. The visual analysis of the worker's body movement enabled Gilberth to specialize every single movement in order to increase the entire productivity of the human body in the factory. The maximization of efficiency implied a substantial reduction of waste. Gilberth understood movement as a phenomenon full of eccentricities and because of that he stressed the necessity of a science of movement at the base of a normative practice. Nonetheless, the most surprising issue is that Gilberth's studies are not considered very precise or useful other than their promotional value, as they provided an ideal image of scientific management and, simultaneously, a commercially seductive image of his own method (Curtis, 2009, p. 86). Even if his work provided a resource for Taylorism in the factory, its most important worth depended on the persuasive value of the image and on the social life that these images achieved. Gilberth's films were simultaneously scientific experiments themselves, but also, commodities to sell to industrial managers. "It is important to note that whatever the distribution, Gilberth is deriving significant productivity from his films" (Curtis, 2009, p. 86). Part of 
these films' managing efficacy depended on the spectacle of efficiency. Gilberth's films included a geometrical and monochrome backstage-clearly emulating Muybridge's - and a chronometer to create the sensation of a pure scientific approach. Its edition process suggested a clear and quantified increase of productivity after the implementation of the results of micro-motion observation. This narrative rhetoric was the base of the exposition of efficiency. Despite this scientific surrounding, his filmic approach seemed to prefer a spectacular visual condition to a positivist form of observation. "Gilberth only rarely filmed his subject from an appropriate angle and height if he were indeed interested in taking accurate measurements from the photograph" (Curtis, 2009, p. 89). Therefore, Gilberth films seem to be closer to educative and persuasive images than to a scientific experiment, properly speaking. Even if Gilberth looked for a scientific approach, the structure of his images expressed how the spectacle of scientific efficiency is needed by science and commodity. In other words, science as commodity behaves as a fetish in the context of modernity, and so filmic technique provides a perfect resource to aestheticize the management of bodies. That is why Gilberth ended up working in areas such as sports, so he could finally gain a larger audience. And in sports, as in the factory, he seemed to sell more the technique of observation than an actual management solution. "Gilberth appears to be selling solutions, but he is really selling a process of visualizing an imagined solution, an utopian efficiency. He is mostly selling the technique and wonder of the camera" (Curtis, 2009, p. 96). Gilberth's case expresses perfectly the efficiency of technique as the ideal justification for fetishism of the technical forms of the gaze. From Frank B. Gilberth to current films such as The Matrix, Avatar, and Transformers, cinematographic devices are glorified because of their apparent visual autonomous efficiency.

As soon as cinematographic production adopted Taylorism as its basic ideology, as soon as cinema integrated the division and specialization of labors, as soon as motion picture assumed the production of artistic commodities, the same rationality embodied in the film, in the camera and in the projector tended to be transferred to the human body on the screen. If Gilberth achieved the spectacle of efficiency through the analysis of the worker's body, cinema strived, as a widespread trend, to achieve the 
efficiency of spectacle through its emerging rhetoric of the show business. In other words, the will to management crystallized in the material technique base of cinema was mostly transferred in silence to films as aesthetic commodities. That is why Giorgio Agamben finds an ambiguous position of cinema in these politics of the body. For him, modernity is the context in which human gestures are in danger and cinema is a privileged scenario where this danger takes place. "In the cinema, a society that has lost its gestures tries at once to reclaim what it has lost and to record its loss" (Agamben, 2000, p. 63). The body became an object of normalization, which entailed the expropriation of gestures from modern people. As Agamben (2000) suggests, cinema is, according to its social function in modernity, a place where an ambiguous struggle for gestures happens:

\begin{abstract}
When the age realized this, it then began (but it was too late!) the precipitous attempt to recover the lost gestures in extremis. The dance of Isadora Duncan and Sergei Diaghilev, the novel of Proust, the great Jugendstil poetry from Pascoli to Rilke, and, finally and most exemplarily, the silent movie trace the magic circle in which humanity tried for the last time to evoke what was slipping through its fingers forever. (Agamben, 2000, pp. 63-64)
\end{abstract}

During the first decades of early cinema, before its industrialization, the projection of short films full of bodies and movements free of any measure or law, brought to the screen just to be seen, was usual. The early cinema screen was plagued of movement, which was exhibited for the simple pleasure of the visual and lacked a codification according to a system of signification. This cinema, described by Tom Gunning as cinema of attractions, provided a very different set of bodies. "It is precisely this harnessing of visibility, this act of showing and exhibition, which I feel cinema before 1906 displays most intensely" (Gunning, 1990, p. 56). The preindustrial mode of production kept the body out of the reductive frame of narrative signification. "The, 'cinema of attractions', in its emphasis on theatrical display, is opposed to the diegetic absorption of the later classical cinema" (Doane, 2002, p. 24). Early cinema exploited the disturbing lack of sense by displaying images without anything to be read. The camera was not conceived as an element integrated to a process of efficient production of meaning and neither were the bodies of actors and actresses. "One characteristic of cin- 
ema set it apart from earlier processes of representing time, such as writing and music, and associated it with the ever-present and consistently disturbing potential of meaningless, of providing the spectator with nothing to read" (Doane, 2002, p. 63). Thus, it is possible to state that, in early cinema, cinematic technique denied its administrative provenance. The direct experience of time as randomness also implied an experience of meaninglessness and so, an experience of the body as a matrix of movement, free of mechanical codes.

Early filmmaking makes manifest a rhetoric of the human form, turning
the body itself into an expressive medium. To achieve any sort of con-
ceptual unity, in other words, practices of cinema on its first decade
come to rely most crucial on the dynamic language of body move-
ment-gestures, comportments, and attitudes. (Auerbach, 2007, p. 2)

As soon as the industrial system became the model of cinematographic production, the cinematic image silently absorbed its economy in terms of aesthetic codes, narrative regulations, editing canons, performance models, and staging laws. In this case, the entire body represented on the screen absorbed the industrial economy through an Institutional Mode of Representation (Burch, 1990), the so-called Language of Cinema. The efficiency system of values that is at the core of the technical base of the cinematic image was soon transferred to the body of the actors and actresses:

The "scientific" fragmentation described by Agamben is not always visible within cinematic aesthetics which, while adopting its means, attempts to obscure them, reconstructing the body as a whole, a complete object. But the divisible body remains as the invisible heart of cinema's corporeal display. (Levitt, 2000, p. 29)

The body is segmented through the montage in order to optimize its presence in terms of narration and drama, but that division is hidden as part of that efficiency.

Bodily movements and gestures are isolated through the choice and juxtaposition of film clips. Probably the clips are not chosen specifically for their gestural dimension, but in effect the fullness of narrative unfolding, which is usually the unfolding of character, is reduced to bodily dispositions. (Stern, 2012, p. 25) 
In other words, the dramatic analysis of the body invented by D. W. Griffith resonates with the spirit of the administrative spectacle of science from the so-called pioneers of cinema. Walter Benjamin (2009) offers a very rich approach to this mechanization of actors' bodies hidden behind the idea of the meaningfulness of their performance. Actors' bodies are tested by technique in terms never experienced before by any theater actor. He compares the theater actor and the film actor and finds a shift that depends, at least partially, on the mediation of technical devices in an industrial system of production:

The stage actor identifies himself with the character of his role. The film actor very often is denied this opportunity. His creation is by no means all of a piece; it is composed of many separate performances. Besides certain fortuitous considerations, such as cost of studio, availability of fellow players, décor, etc.; there are elementary necessities of equipment that split the actor's work into a series of mountable episodes. In particular, lighting and its installation require the presentation of an event that, on the screen, unfolds as a rapid and unified scene in a sequence of separated shootings which may take hours at the studio. (Benjamin, 2009, p. 675)

The actor's performance turned into a mixed function of economy, art and technique ${ }^{5}$. Therefore, the actor's performance became as testable as technique elements or human productive skills. The management methods implemented by canonic filmmaking is not surprising, its function being to control the spectacle of actors and actresses' bodies according to a model of commercial and artistic efficiency. From delicate beauty tests in

5 A perfect contrasting example is provided by Martin Arnold's experimental cinema. He became famous because of his alteration of the mechanism of the cinematic image. He uses preexistent material in his work, as well as footage found in classic Hollywood films, to alter them. Arnold edits the film by repeating frames and thus making the image jump as a product of the alteration that stretches out small fragments into long sequences of repetitions, where bodies repeat over and over their movements, exposing the same singular gestures to satiety. Then, the bodily movements of the actor turn into a mechanical choreography of repetitions, intensified due to the repetition of sound as well. This game of repetitions reveals the invisible mechanisms of bodies in the original film. In "Alone. Life Wastes Andy Hardy" (1998), he obsessively repeats fragments of a film in which a son hugs his mother from the back. The effect of repetition produces a sexual subtext that reveals an unconscious choreography of bodies and simultaneously deconstructs the official choreography of the classical mainstream Hollywood film. This alteration of film mechanism reveals what is supposed to remain hidden: the calculated system of bodies before the lenses. Mechanical alteration denounces the corporeal imposture; the prison that encloses bodies in the screen. 
different positions and shoots in a casting, to tests of separate parts of the body to construct a perfect character according to each role, bodies are exposed to permanent filmic tests. Cinema is the art of tests: camera tests, light devices tests, dressing tests, make up tests... To phrase it in technical language: Cinema is the art of preproduction.

The expansion of the field of the testable which mechanical equipment brings about for the actor corresponds to the extraordinary expansion of the field of the testable brought about for the individual through economic conditions. Thus, vocational aptitude tests become constantly more important. What matters in these tests are segmental performances of the individual. The film shot and the vocational aptitude test are taken before a committee of experts. The camera director in the studio occupies a place identical with that of the examiner during aptitude tests. (Benjamin, 2009, p. 674)

In an industrial system of production, the body tends to inherit the mechanism of the system, that is, the set of repetitions and divisions characteristic of its model of efficiency. Technical devices are not only historically designed, but they also transfer their design to reality.

However, it is important to remark that this normalization of the body through cinema is not a necessary step resulting from the technical grounds of cinema, but is rather a result of an industrial appropriation of new means. Neither technique nor industry has a destiny in themselves.

\section{Cinematic Technique, Body and the Economy of the Soul}

The way the human body adopted the behavior of technique is visible on the screen. It allows us to see that cinematic technique crystallizes a modern system of values, as well as how that technique also impregnates images seen by spectators. Nonetheless, it is not necessary to reduce cinematic technique to optical devices. Cinematographic technical clothing not only consists of lenses, the camera and the projector, just as industrial procedures to produce a film are not reduced to the shooting of a movie. Jean-Louis Comolli (1980) insists on how unconstructive this bias can be: "The example given is always that which produces the cinematic image, and 
it alone, considered from the sole point of view of optics" (Comolli, 1980, p. 124). That prejudgment implies the privilege of what is to be seen over what is not visible. The privilege of the camera supposes the bias of spectacle that reduces everything to what is visible. It is also necessary to understand that the camera does not exhaust cinematic technique. Neither the construction of a film nor the images projected on the screen are reducible to optical devices. The extent of the issue is broader because cinematic technique entails more than mere visual components. Comolli (1980), again, provides a very helpful assessment:

To elect the camera as "delegated" of the whole of cinematic equipment is not merely synecdochycal (the part for the whole). It is above all an operation of reduction (of the whole to the part), to be questioned in that, theoretically, it reproduces and confirms the split which is ceaselessly marked in the technical practice of cinema (not only in the practice of film-makers and technicians and in the spontaneous ideology of its practice; but also in the idea, the ideological representation that spectators have of work in cinema: concentration on shooting and studio, occultation of laboratory and editing) between the visible part of the technology of cinema (camera, shooting, crew, lighting, screen) and its "invisible" part (black between frames, chemical process, baths and laboratory work, negative film, cuts and join of editing, sound track, projector, etc.), the latter repressed by the former, generally relegated to the realm on the unthought, the "unconscious" of cinema. (p. 125)

As Comolli remarks, the quantity of studies on the visual part of cinematic work is vastly superior to the quantity on the non-visual but fundamental work behind the screen. The emulsion, diaphragm system, and even technical instructions at the school are as fundamental to cinema as lenses and the camera. All of them make part of what is called cinematic technique. This simple lack of theory expresses the hegemony of the visual in cinema as a bias that traverses cinema from the script to the film festival. That is why the emphasis on the heritage of cinema from the Renaissance's perspective has been a common feature. ${ }^{6}$ That emphasis disregards the chemical, physical and even economical debts that cinematic devices have with history.

6 Jonathan Crary (1990) claims that, despite the usual opinion that assumes continuity between cinema and Renaissance painting, it is necessary to reformulate the issue. For him, even if cinema reproduces reality through the image as Renaissance painting does, the visual effect of movements depends on a rupture with classic tradition, which 
The very well known work by Jonathan Crary elaborated in his two famous books, Techniques of the Observer (1990) and Suspensions of Perception (2001), aims to make visible the structural relation between technical devices, scientific discourse and standardized practices at the base of audio-visual technologies emerging during the nineteenth and the twentieth centuries. For him, an accurate approach to modern societies of spectacle depends on the recognition of the new regime of perception and attention that emerged in the nineteenth century along with science, theory and positivist experimentation. In other words, he argues that cinematographic technical devices were only possible by coexisting with some techniques of the observing and attentive modern subject. Technical devices of the image and technical scientific procedures and discourses are articulated in the emergence of the modern observer and subject of attention. Part of the social life of modern technique goes through the social life of modern science. The establishment of a quantitative model for perception, or of measurable canons for attention, fits perfectly with the implementation of photography or film technology in the theater. The technique of bodies projected on the screen harmonizes with the technique of the attentive eyes before the screen. The analysis of the movement of the recorded bodies projected on the screen resonates with the accurate studies on the perceptive and attentive body of the spectator who paid for his ticket. When Crary summarizes the importance of Muybridge's visual devices, he manifests that:

Muybridge's work obviously opened up possibilities for the rationalization and quantification of movement and time, for the mechaniza-

\footnotetext{
assumes the role of a passive observer. Cinema and modern philosophical toys depend on a new conception of observer created during the first three decades of the nineteenth century. This new conception of visual perception considers the observer as active, insofar as his/her body intervenes in the processes of perception. This materialization of perception processes through the body allows its quantification and calculation. As a result, Crary confirms a rupture where traditional approaches have seen continuity: "My concern is how the individual as observer became an object of investigation and a locus of knowledge beginning in the first few decades of the 1800s, and how the status of the observing subject was transformed. As I have indicated, a key object of study in the empirical sciences then was subjective vision, a vision that had been taken out of the incorporeal relations of the camera obscura and relocated in the human body. It is a shift signaled by the passage from the geometrical optics of the seventeenth and eighteenth centuries to physiological optics, which dominated both scientific and philosophical discussion of vision in the nineteenth century. Thus knowledge was accumulated about the constitutive role of the body in the apprehension of a visible world, and it rapidly became obvious that efficiency and rationalization in many areas of human activity depended on information about the capacities of the human eye" (Crary, 1990, p. 16).
} 
tion of the body, but, equally importantly, it posed plural scatterings of attention and the possibility of unforeseen perceptual syntheses outside of any disciplinary imperatives. (Crary, 2001, p. 147)

For Crary, Muybridge not only analyzed the recorded body but he also-and unconsciously_-participated in the emergence of a new kind of observer whose gaze could be formulated quantitatively in terms of a scientific experimental discourse, and could also be normalized according to certain models of a productive attention. Technology for spectacle and technique of the attentive subject soon would correspond:

Early in the twentieth century these two poles (the technological and the oneiric) would become overlapping elements within a generalized organization of spectacle, in which a systematic understanding of perceptual synthesis is a prerequisite for the technological production of managed and consumable forms of dissociation. (Crary, 2001, p. 148)

For Crary, the comprehension of what perception is completely changed in the second decade of the nineteenth century. The model of vision modernized:

Very early on in the nineteenth century the camera obscura collapses as a model for an observer and for the functioning of human vision. There is a profound shift in which an observer is described, figured and posited in science, in philosophy, and in new techniques and practices of vision. (Crary, 2009, p. 207)

This shift depended on the loss of credibility of the model of the camera obscura. The idea of a monocular vision, of a passive structure of subjective perception and of an immaterial and isolated faculty of perception was destroyed. The core of this shift consisted in a revaluation of the body of the observer. The body began to be included as a new term in the discourses and practices on visual perception. The body is taken into account "in all its physiological density as the ground on which vision is possible" (Crary, 2009, p. 207). Thus, perception stopped being a transparent and passive sense of an observer and became an active faculty determined by the physiological constitution of the observer's body. The new concern 
regarded how the perceptive body functioned and what kind of new machines and procedures could actually evaluate this work. In consequence, the body of the observer was subjected and normalized by this new kind of knowledge and its correlative discourses and institutions. However, this change was not simply a scientific shift; scientists, artists and philosophers also shared this new model of perception. This generalized emphasis on the body brought with it new forms of organization of visuality. In the context of the emerging anatomo-politics, the transformation of vision into a function of the body entailed an administration of perception that was typically modern:

Thus knowledge was accumulated about the constitutive role of the body in the apprehension of a visible world, and it rapidly became obvious that efficiency and rationalization in many areas of human activity depended on information about the capacities of the human eye. (Crary, 1990, p. 16)

The activity of the eye became a quantifiable work. Once the eye's functions became measurable in terms of intensity and duration, they became predictable and controllable. The control of the body is not reduced to the prison or to the factory. In a different level, and through different strategies, the organic functions of the spectator tend to be governed in modernity as well. In fact, the final expectation was as follows: the quantification of the eye's processes of perception could provide the grounds to establish positivist norms of human attention through the corporeal analysis of perception. The knowledge of the body could be projected as a form of knowledge and discipline of soul. The quantitative knowledge of the body could be the entrance point for the quantitative knowledge of attention framed by the industrial system of production and consumption. From the worker at the factory to the spectator at the theater and the consumer before the shopping window, the multidisciplinary concern on attention is fundamental for the modern sensitivity:

At the moment when the dynamic logic of capital began to dramatically undermine any stable or enduring structure of perception, this logic simultaneously attempted to impose a disciplinary regime of attentiveness. For it is in the late nineteenth century, within the human sciences and particularly the nascent field of scientific 
psychology, that the problem of attention becomes a fundamental issue. (Crary, 2001, p. 13)

The incarnation of perception in attentiveness opened the possibility to analyze the human soul's activity in new terms: "In particular, attention was studied in terms of response to machine-produced stimuli, often electrical in nature and abstract in content, that allowed a quantitative determination of the sensory capacities of a perceiving subject" (Crary, 2001, p. 27). The new language of attention was the language of numbers and laws. The soul became a problem of quantities and intensities to be translated into the language of "natural" rules of behavior. Concrete human reactions turned into numerical representations, and so they became an input of the system of normalization of attention to produce at the factory and to consume in front of the spectacle of commodities. The truth about the body, perception and attention has to be brought to the land of standardization and its correlative formalization. Anatomo-politics covered a wider space than Foucault conceived, and thus modern acts of power could be tracked in more heterogeneous scenarios. From the docile soul of the prisoner to the attentive eye of the spectator the body was in the core.

vision itself became a kind of discipline or mode of work. The nineteenth-century optical devices I discuss, no less than the panopticon, involved arrangements of bodies in space, regulations of activity, and the deployment of individual bodies, which codified and normalized the observer within rigidly defined systems of visual consumption. They were techniques for the management of attention. (Crary, 1990, p. 18)

In this context, it is clear why hundreds of handbooks for scriptwriting respect what is usually called "the structure." This term refers to a narrative structure full of dramatic pivotal points mathematically distributed along the timeline of the story. For example, for a two-hour movie, a plot point is needed between minute twenty-three and twenty-five to pass from the first act to the second. The narrative structure supposes a mathematic scheme of the timeline that corresponds to an accurate geometry of the attention of the spectator. The quantification of attention is translated into a will to calculate the spectator's affects. Minute by minute, the time 
of narration is governed by a technical scheme of the soul. If the body of the actor adopted the aforementioned form of cinematic technique, the form of the narration inherited the principles of quantification and formalization of the attention characteristic of experimental psychology. At this point, it is important to remark that the evolution of the idea of attention expresses a transformation of modern societies. The disciplinary system described by Foucault is the prehistory of what societies of attention are. Even if they are related, the set of mechanisms of power that burden the prisoner are different to the silent but effective non-repressive mechanisms for the control of attention. Nevertheless, the relation can be tracked in some common points.

\section{References}

Agamben, G. (2000). Means without end. Minneapolis, MN: University of Minnesota Press.

Arnold, M. (2009). Vilém Flusser. In F. Collman, (Ed.), Film, theory and philosophy: The key thinkers (pp. 31-39). Montreal, Canada: McGill-Queen's University Press.

Auerbach, J. (2007). Bodyshots. Los Angeles, CA: University of California Press.

Benjamin, W. (2005). News about flowers. In M. W. Jennings, H. Eiland, \& G. Smith (Eds.), Walter Benjamin: Selected writings (Vol. 2, Part 1, pp. 179-187). Cambridge, MA: Harvard University Press.

Benjamin, W. (2009). The work of art in the age of mechanical reproduction. In L. Braudy \& M. Cohen (Eds.), Film, theory and criticism (pp.665-685). New York, NY: Oxford University Press.

Burch, N. (1990). Life to those shadows. Berkeley, CA: California University Press. 
Comolli, J. -L. (1980). Machines of the visible. In T. de Laurentis \& S. Heath (Eds.), The cinematic apparatus (pp. 121-142). London, UK: MacMillan.

Crary, J. (1990). Techniques of the observer. Cambridge, MA: MIT University Press.

Crary, J. (2001). Suspensions of perception. Cambridge, MA: MIT University Press.

Crary, J. (2009). From vision and visuality: Modernizing vision. In L. Braudy \& M. Cohen (Eds.), Film, theory and criticism (pp. 206-215). New York, NY: Oxford University Press.

Curtis, S. (2009). Images of efficiency: The films of Frank B. Gilbreth. In V. Hediger \& P. Vonderau (Eds.) Films that work (pp. 85-99). Amsterdam, Netherlands: Amsterdam University Press.

Deleuze, G. (1997). The time-image. Minneapolis, MN: University of Minnesota Press.

Didi-Huberman, G. (2003). Invention of hysteria. Cambridge, MA: MIT University Press.

Doane, M. A. (2002). The emergence of cinematic time. Cambridge, MA: Harvard University Press.

Foucault, M. (1990). History of sexuality (Vol. 1). New York, NY: Vintage Books.

Gunning, T. (1990). The cinema of attraction: In early cinema: Space, frame, narrative. London, UK: British film institute.

Hendricks, G. (2001). Eadweard Muybridge: Father of motion picture. New York, NY: Dover. 
Levitt, D. (2002). Image as gesture: The saint in Chrome Dioxide. Retrieved from http://cinema.usc.edu/assets/098/15860.pdf

Oubiña, D. (2009). Una juguetería filosófica. Buenos Aires, Argentina: Manantial.

Pezzella, M. (2004). Estética del cine. Madrid, Spain: Machado libros.

Prodger, P. (2003). Muybridge and the instantaneous photography movement. New York, NY: Oxford University Press.

Sibilia, P. (2005). El hombre postorgánico. Buenos Aires, Argentina: Fondo de Cultura Económica.

Sirois-Trahan, J. -P. (2009). Movies, new imperialism, and the new century. In A. Gaudreault (Ed.), American Cinema 1890-1909: Themes and variations (pp. 91-111). New Brunswich, NJ: Rutgers University Press.

Stern, L. (2012). Always too small or too tall. In J. Sternagel, D. Levitt, D. Mersch, \& L. Stern (Eds.), Acting and performance in movie image cultures (pp.11-49). New Brunswick, NJ: Rutgers University Press. 